\title{
Pengaruh Pendekatan Brain-Based Learning terhadap Kemampuan Komunikasi Matematis dan Self-Efficacy Siswa SMA
}

\author{
Heru Sukoco $^{1}{ }^{*}$, Ali Mahmudi ${ }^{2}$ \\ ${ }^{1}$ Jurusan Pendidikan Matematika, Universitas Mercu Buana Yogyakarta, Jalan Wates Km 10, Daerah \\ Istimewa Yogyakarta 55753, Indonesia \\ 2 Jurusan Pendidikan Matematika, Universitas Negeri Yogyakarta, Jalan Colombo No. 1, \\ Karangmalang, Yogyakarta 55281, Indonesia \\ * Korespondensi Penulis. Email: herusukocomath@gmail.com, Telp: +6285228289094
}

Received: 15 ${ }^{\text {th }}$ June 2016; Revised: $26^{\text {th }}$ July 2016; Accepted: $26^{\text {th }}$ July 2016

\begin{abstract}
Abstrak
Penelitian ini bertujuan untuk mendeskripsikan pengaruh pembelajaran dengan pendekatan Brain-Based Learning (BBL) terhadap kemampuan komunikasi matematis (KKMAT) dan selfefficacy siswa. Penelitian ini merupakan penelitian eksperimen semu menggunakan desain grup kontrol tidak secara acak dengan pemberian tes awal dan tes akhir. Populasi penelitian ini adalah seluruh siswa kelas XI IPA SMA Negeri 1 Jetis Daerah Istimewa Yogyakarta pada semester kedua tahun ajaran 2012/2013 yang terdiri atas tiga kelas. Dua kelas dipilih sebagai sampel penelitian, yaitu kelas eksperimen dan kelas kontrol. Instrumen yang digunakan dalam penelitian ini adalah tes KKMAT dan skala self-efficacy. Data penelitian dianalisis menggunakan uji t dan uji multivariat (MANOVA). Hasil penelitian ini menunjukkan bahwa pembelajaran dengan pendekatan BBL berpengaruh terhadap kemampuan komunikasi matematis dan self-efficacy siswa.
\end{abstract}

Kata Kunci: Pendekatan Brain-Based Learning, kemampuan komunikasi matematis, self-efficacy

\section{The Effect of Brain-Based Learning Approach toward the Mathematical Communication Ability and Self-Efficacy of Senior High School Students}

\begin{abstract}
This study aimed to describe the effect of the instruction using Brain-Based Learning Approach (BBLA) toward students' mathematical communication ability (MCA) and self-efficacy. This study adopted a pretest-posttest nonrandomized control group design in a quasi-experimental setting. The population comprised all students grade XI IPA of SMA Negeri 1 Jetis D. I. Yogyakarta in the second semester of the academic year 2012/2013 consisting of three classes. Two classes were selected as the research sample, namely experimental class and control class. The instruments of the study were a test of MCA and scale of self-efficacy. The data were analized using the one sample t test and MANOVA test. The findings of the study show that the instruction using BBLA has an effect on students' mathematical communication ability and self-efficacy.
\end{abstract}

Keywords: Brain-Based Learning Approach (BBLA), mathematical communication ability, selfefficacy

How to Cite: Sukoco, H., \& Mahmudi, A. (2016). Pengaruh pendekatan brain-based learning terhadap kemampuan komunikasi matematis dan self-efficacy siswa SMA. PYTHAGORAS: Jurnal Pendidikan Matematika, 11(1), 11-24. doi:http://dx.doi.org/10.21831/pg.v11i1.9678

Permalink/DOI: http://dx.doi.org/10.21831/pg.v11i1.9678 


\section{PENDAHULUAN}

Matematika memiliki peranan penting dalam peningkatan kualitas sumber daya manusia. Matematika merupakan ilmu universal yang mendasari perkembangan teknologi modern, mempunyai peran penting dalam berbagai disiplin dan memajukan daya pikir manusia (Peraturan Pemerintah Nomor 22, 2006). Penguasaan matematika sejak dini sangat diperlukan dalam mempersiapkan generasi penerus bangsa yang kreatif, inovatif, dan memiliki daya saing tinggi. Oleh karena itu, tingkat penguasaan matematika dapat dijadikan sebagai tolak ukur kemajuan suatu bangsa.

Akan tetapi, matematika merupakan salah satu mata pelajaran yang sulit (Muijs \& Reynolds, 2005, p.212). Selain itu, bukan menjadi rahasia lagi bila banyak siswa tidak menyukai matematika karena adanya pandangan dari orang tua, guru, atau orang-orang sekitarnya yang sering mengatakan bahwa matematika merupakan mata pelajaran yang sulit. Kesulitan siswa mempelajari matematika juga disebabkan oleh sifatnya yang abstrak dan membutuhkan kemampuan berpikir logis serta terurut (Sousa, 2008, p.2). Berdasarkan beberapa alasan tersebutlah, tidak mengejutkan bila sebagian besar siswa tidak cukup tertarik dan yakin mampu mempelajari matematika dengan baik.

Berdasarkan hasil TIMSS 2011 (Mullis et $a l, 2012$, p.42), tingkat penguasaan siswa-siswi Indonesia pada mata pelajaran matematika atau prestasi belajar matematika untuk kelas 8 masih rendah karena hanya memperoleh skor 386 , dengan rata-rata skor internasional adalah 500 . Skor tersebut menempatkan Indonesia pada peringkat ketiga terbawah. Bila dibandingkan dengan tahun 2007 yang memperoleh skor 397, terjadi penurunan sebesar 11 poin pada tahun 2011. Berdasarkan hasil pengukuran tersebut, dapat disimpulkan bahwa prestasi belajar matematika untuk kelas 8 di Indonesia dalam kurun waktu 2007-2011 tidak mengalami perubahan yang berarti dan cenderung menurun.

Prestasi belajar matematika yang masih rendah berdasarkan survei TIMSS diduga terkait dengan rendahnya kemampuan komunikasi matematis siswa. Salah satu penyebab rendahnya prestasi belajar matematika tersebut adalah kurangnya pemahaman siswa terhadap konsepkonsep yang terdapat dalam matematika yang disebabkan karena siswa kurang mendapat kesempatan untuk melakukan komunikasi dan pemecahan masalah matematis (Kusnaeni \&
Retnawati, 2013). Menurut Mullis et al (2012, p.113), soal-soal pada TIMSS khususnya untuk siswa kelas 8 membutuhkan kemampuan komunikasi yang baik adalah (1) mampu menghubungkan gambar dua dimensi sampai objek tiga dimensi, (2) mampu membaca, mengintepretasikan, dan mengkonstruksi grafik dan tabel, (3) mampu menganalisis data di dalam berbagai jenis grafik, (4) mampu mengekspresikan sifatsifat aljabar secara umum, (5) mampu memberikan alasan dengan gambar secara geometri untuk menyelesaikan soal/masalah, dan (6) Mampu memberikan alasan dengan data dari berbagai sumber atau representasi yang tidak biasa untuk menyelesaikan masalah-masalah non rutin.

Pentingnya kemampuan komunikasi matematis secara jelas juga termuat dalam Peraturan Pemerintah Tahun 2006 tentang Standar Isi. Salah satu tujuan mempelajari matematika di sekolah, seperti dijelaskan dalam standar isi, adalah agar siswa mampu mengkomunikasikan gagasan dengan simbol, tabel, diagram, atau media lain untuk memperjelas keadaan atau masalah (Peraturan Pemerintah Nomor 22, 2006). Untuk mewujudkan tujuan tersebut, siswa perlu diberikan keleluasaan berpikir sesuai dengan kemampuan otaknya masing-masing. Dengan kata lain, belajar matematika bukan hanya mengenai rumus dan perhitungan tetapi lebih menekankan pada bagaimana siswa mampu mengkontruksikan ide dan menggunakan logikanya dengan baik.

Selain dari pihak siswa, hendaknya guru membekali siswa dengan kemampuan komunikasi sejak dini agar mereka mampu bersaing dalam menghadapi era pasar bebas yang akan datang. Bahkan sejak tahun 1991, The Secretary's Commission on Achieving Necessary Skill (SCANS) menjadikan kemampuan komunikasi matematis sebagai salah satu kemampuan dasar yang hendaknya dikuasai oleh siswa dalam menunjang karirnya nanti pada dunia kerja. Lembaga tersebut merupakan salah satu lembaga di bawah departemen tenaga kerja Amerika Serikat. Secara khusus dijelaskan bahwa kemampuan dasar tersebut adalah menggunakan data kuantitatif untuk membangun penjelasan logis dalam situasi dunia nyata dan mengekspresikan ide-ide matematika dan konsep secara lisan dan tertulis (The Secretary's Commission on Achieving Necessary Skill, 1991).

National Council of Teachers of Mathematics (NCTM) juga memberikan gambaran yang jelas mengenai pentingnya kemampuan komunikasi bagi siswa ketika belajar matema- 
tika. Ketika siswa mencoba berpikir dan mencari alasan tentang matematika lalu mengkomunikasikan hasil pemikiranya tersebut secara lisan maupun tulisan kepada orang lain, maka siswa tersebut telah belajar secara jelas dan meyakinkan (NCTM, 2000, p.60).

Kilpatrick, Swafford, \& Findell (2001, p.130) mengatakan bahwa siswa harus mampu membenarkan dan menjelaskan ide-ide untuk membuat penalarannya jelas, mengasah kemampuan bernalar, dan meningkatkan pemahaman konsepnya. Jika dipahami lebih mendalam, kata "membenarkan dan menjelaskan" kurang lebih mengarah kepada kemampuan komunikasi matematis siswa. Kemampuan tersebut merupakan salah satu bagian dari kecakapan yang harus dimiliki siswa dalam mempelajari matematika dan dalam penelitian ini disebut sebagai kemampuan komunikasi matematis.

Indikator-indikator dari kemampuan komunikasi matematis menurut Principles and Standards for School Mathematics (NCTM, 2000, p.60) adalah (1) mampu mengorganisasikan dan mengkonsolidasikan pemikiran matematis melalui komunikasi, (2) mampu mengkomunikasikan pemikiran matematis secara koheren dan jelas kepada siswa lain, guru, dan orang lain, (3) mampu menganalisis dan mengevaluasi pemikiran matematis dan strategi-strategi siswa lain, dan (4) Mampu menggunakan bahasa matematis untuk mengekspresikan ideide matematis secara tepat.

Lebih lanjut, menurut Ontario Ministry of Education (2005, p.21), komunikasi matematis mencakup tiga indikator, yaitu (1) mengekspresikan dan mengorganisasikan ide-ide dan berpikir secara matematis (kejelasan ekspresi, orgasisasi logis), menggunakan bahasa lisan, visual, dan bentuk tertulis (misalkan gambar, grafik, hitungan, bentuk aljabar; materi-materi dalam bentuk konkret), (2) komunikasi untuk audiensi yang berbeda (misalkan siswa lain, guru) dan tujuan (misalkan menampilkan data, membenarkan penyelesaian, dan mengungkapkan pendapat secara matematis) secara lisan, visual, dan tertulis, dan (3) menggunakan konvensi, kosakata, dan istilah dari matematika (misalkan istilah, simbol) secara lisan, visual, dan tertulis.

Masalah lain yang diduga erat kaitannya dengan prestasi belajar matematika yang masih rendah adalah rendahnya keyakinan siswa terhadap kemampuan diri sendiri, baik dalam belajar maupun menghadapi soal-soal atau masalah matematika. Berdasarkan observasi yang pene- liti lakukan pada bulan Februari 2013, diketahui bahwa sebagian besar siswa kelas XI IPA di SMAN 1 Jetis Bantul masih takut salah ketika diminta guru untuk menuliskan dan menjelaskan hasil pekerjaannya di depan kelas. Siswa takut salah karena tidak yakin dengan jawaban yang mereka peroleh dan juga tidak yakin mereka mampu menjelaskan dengan baik. Kesimpulan tersebut merupakan hasil wawancara langsung peneliti kepada siswa.

Hasil observasi juga memperkuat dugaan peneliti bahwa rendahnya prestasi belajar siswa erat kaitannya dengan self-efficacy siswa yang masih rendah. Bandura (1997, p.3) mengatakan bahwa keyakinan seseorang terhadap kemampuan mereka dalam mengatur dan menjalankan program tindakan yang diperlukan untuk menghasilkan pencapaian yang diberikan disebut selfefficacy. Selain itu, Liu \& Koirala (2009, p.9) dalam penelitian surveinya yang mengambil subjek siswa kelas 10 di Amerika Serikat, menemukan bahwa self-efficacy dan prestasi matematika mempunyai korelasi yang positif. Artinya bahwa, semakin tinggi self-efficacy matematis seorang siswa, semakin baik pula prestasi matematikanya atau sebaliknya. Hal ini diperkuat oleh hasil penelitian Hamdi \& Abadi (2014), bahwa self-efficacy berpengaruh terhadap prestasi. Siswa yang memiliki self-efficacy tinggi akan lebih siap dalam menghadapi berbagai situasi dan mampu menghasilkan hal-hal positif dalam hidupnya. Menurut Zimmerman (Bandura, 1995, p.203), self-efficacy akademis didefinisikan sebagai penilaian seseorang terhadap kemam-puannya dalam mengatur dan melaksanakan program kerja untuk mencapai jenis prestasi dalam pendidikan yang telah ditunjuk. Self-efficacy bukan berarti "seseorang percaya dengan apa yang akan dilakukannya" tetapi lebih kepada "seseorang percaya dengan apa yang mampu dilakukannya". Keyakinan seseorang akan efficacy-nya, menurut Bandura (1995, p.3; 1997, p.79), dapat dikembangkan dari empat sumber utama, yaitu pengalaman kinerja (enactive mastery experiences/performance experience), pengalaman orang lain (vicarious experience), pendekatan verbal atau pendekatan sosial (verbal persuasion/social persuasion), dan bentuk psikologis dan afektif (physiological and affective states).

Sumber paling penting dalam membangun rasa efficacy seseorang adalah enactive mastery experience. Kegagalan atau keberhasilan seseorang di masa lalu dapat memberikan bukti paling autentik apakah dirinya mampu memper- 
siapkan apa saja yang diperlukannya untuk meraih sukses di masa depan. Sumber pembangun rasa efficacy selanjutnya adalah pengalaman orang lain (vicarious experience). Pengalaman autentik bukan satu-satunya cara untuk menilai kemampuan seseorang. Pengalaman orang lain dapat dijadikan pembanding seberapa berhasil pencapaian yang telah dilakukannya selama ini. Dengan demikian, rasa efficacy seseorang akan timbul dan berkembang melalui transfer kemampuan dan perbandingan dengan pengalaman yang telah diperoleh orang lain.

Melengkapi kedua sumber tersebut, sumber pembangun rasa efficacy yang selanjutnya adalah pendekatan verbal atau pendekatan sosial (verbal persuasion/social persuasion). Pendekatan tersebut merupakan cara ketiga untuk memperkuat keyakinan seseorang bahwa mereka memiliki apa yang diperlukan dalam meraih kesuksesan. Menurut Johnston (Arends \& Kilcher, 2010, p.63) penggunaan bahasa yang baik dapat memaksimalkan self-efficacy siswa. Komentar atau masukan yang positif dari lingkungan terhadap kemampuan seseorang akan memperkuat efficacynya. Akan tetapi, komentar atau masukan yang negatif dapat berakibat buruk karena jika dilakukan berkelanjutan akan menghilangkan rasa efficacy dan kepercayaan diri sese-orang. Selanjutnya, sumber pembangun rasa efficacy yang terakhir adalah bentuk psikologis dan afektif (physiological and affective states). Dalam menilai kemampuannya, seseorang juga mengandalkan sebagian informasi somatis yang disampaikan dalam bentuk-bentuk psikologis dan emosional. Seseorang menafsirkan reaksi stress dan ketegangan sebagai tanda mereka telah melakukan kinerja yang buruk. Suasana hati juga mempengaruhi penilaian seseorang tentang efficacy yang dimilikinya. Ketika menstruasi, karena pengaruh hormon, perempuan cenderung dalam suasana hati yang tidak baik sehingga jika mengerjakan sesuatu maka hasilnya menjadi kurang maksimal.

Bandura (1997, pp.42-43) berusaha menilai tingkatan, keumuman, dan kekuatan selfefficacy berdasarkan aktivitas dan konteksnya. Perlu dicatat bahwa konten item dari skala selfefficacy harus merepresentasikan keyakinan seseorang terhadap kemampuannya dalam menghasilkan tingkatan kinerja secara spesifik dan tidak boleh memuat karakteristik yang lain. Menurut Zimmerman (2000, p.83), tingkatan self-efficacy mengacu pada tinggi atau rendahnya keyakinan seseorang tergantung pada kesulitan dari tugas tertentu, sebagai contoh perta- nyaan-pertanyaan open-ended akan meningkatkan kesulitan soal. Keumuman berkaitan dengan pengalihan keyakinan pada seluruh aktivitas, seperti dari Aljabar untuk Statistika. Kekuatan dari efficacy yang dirasakan dapat diukur dengan seberapa yakin seseorang dapat memastikan mengenai pelaksanaan tugas yang diberikan.

Selanjutnya, bagaimana kaitan selfefficacy dengan kemampuan komunikasi matematis? Morin \& Latham (2000, p.566) menemukan bahwa self-efficacy berkorelasi secara signifikan dengan komitmen tujuan dan kemampuan komunikasi di tempat kerja. Tidak salah jika self-efficacy dikatakan sebagai faktor penting bagi seseorang dalam meraih kesuksesan. Oleh karena itu, self-efficacy dan kemampuan komunikasi matematis siswa perlu difasilitasi dan dikembangkan secara tepat dalam pembelajaran matematika di sekolah karena diduga keduanya saling melengkapi.

Berbagai masalah seperti yang telah diuraikan, jika tidak segera diatasi akan menyebabkan rendahnya mutu pendidikan. Proses pembelajaran di sekolah hendaknya bersifat interaktif, inspiratif, menyenangkan, menantang, dan memotivasi siswa untuk berpartisipasi aktif, serta memberikan ruang yang cukup bagi prakarsa, kreativitas, dan kemandirian sesuai dengan bakat, minat, dan perkembangan fisik serta psikologis siswa tersebut (Peraturan Pemerintah Nomor 41, 2007). Salah satu pendekatan pembelajaran yang memiliki karakteristik yang sesuai dengan arahan pemerintah tersebut adalah pendekatan Brain-Based Learning (BBL).

Menurut Caine \& Caine (1990, p.66), tujuan dari pendekatan BBL adalah mengarahkan pembelajaran dari sekedar menghafal menjadi belajar bermakna. Brain-Based Learning sendiri diartikan sebagai cara belajar yang berpusat pada siswa dengan memanfaatkan seluruh fungsi otak dan mengakui bahwa tidak semua siswa dapat belajar dengan cara yang sama (Duman, 2006, p.17). Cara belajar siswa mengacu bukan hanya mengacu pada potensi gaya/ tipe belajar yang tidak sama, tetapi juga adanya potensi kecerdasan yang berbeda-beda. Tugas guru atau pendidik adalah mengarahkan semua potensi tersebut sehingga diperoleh hasil yang memuaskan.

Pendapat tentang BBL juga dikemukakan oleh Jensen. Menurut Jensen (2008, p.483), BBL lebih berupa toolbox (kotak peralatan) daripada template (pola bagan). Oleh sebab itu, jika dipandang sebagai pendekatan pembelajaran, maka BBL merupakan toolbox pembelajaran 
yang memberi kebebasan kepada siswa untuk mengembangkan potensinya secara alamiah, yaitu berdasarkan cara kerja otak masing-masing. Jadi, pendekatan BBL mengarahkan siswa untuk belajar secara maksimal dengan mengoptimalkan fungsi otaknya. Caine et al (2005, p.2) menjelaskan bahwa BBL mempunyai 12 prinsip utama, yaitu: (1) belajar melibatkan aspek psikologi; (2) otak/pikiran bersifat sosial; (3) mencari sesuatu yang bermakna merupakan bawaan otak sejak lahir; (4) pencarian makna terjadi berdasarkan suatu pola; (5) emosi sangat berpengaruh terhadap pembuatan pola; (6) otak/pikiran memproses sebagian dan keseluruhan informasi secara bersamaan; (7) belajar melibatkan perhatian dan pandangan yang berpusat pada sekelilingnya; (8) belajar dilakukan secara sadar dan tak sadar; (9) terdapat paling sedikit dua pendekatan pada ingatan, yaitu ingatan spasial dan ingatan prosedural; (10) belajar itu berkembang; (11) belajar secara kompleks dapat ditingkatkan melalui tantangan dan dapat dihambat oleh ancaman yang terkait dengan ketidakberdayaan dan atau kelelahan; (12) setiap otak adalah organisasi yang unik.

Tiga instruksi penting ketika menerapkan pendekatan Brain-Based Learning di kelas menurut Caine et al (2005, pp.4-6) adalah sebagai berikut. Pertama, relaxed alertness, yaitu mengusahakan sebuah keadaan di mana siswa bisa "waspada tapi rileks". Hal tersebut berguna untuk menghilangkan rasa takut pada diri siswa, sambil menjaga lingkungan agar tetap menarik dan menantang baginya. Menurut gambaran Jensen (1998, p.57), belajar optimal terjadi ketika siswa berada pada level stres yang relaxed alertness. Kedua, orchestrated immersion, yaitu menciptakan lingkungan belajar yang benarbenar membuat siswa merasa telah masuk ke dalam pengalaman edukatif secara langsung. Ketiga, active processing, yakni kegiatan yang memungkinkan siswa secara aktif melihat, mengkonsolidasi dan menginternalisasi informasi yang datang.

Berikut disajikan langkah-langkah pembelajaran dengan pendekatan BBL yang diintegrasikan berdasarkan 12 prinsip BBL dan tiga instruksi yang dikemukakan oleh Caine et al (2005, p.3) yang telah diuraikan sebelumnya. Langkah-langkah pembelajaran ini dibagi menjadi beberapa tahap, yaitu:

Tahap pertama adalah menciptakan perasaan bermakna ketika memulai pembelajaran di kelas. Tujuannya untuk memfasilitasi siswa dalam mempelajari materi baru yang sebagian besar belum diketahui oleh siswa. Guru memberikan pengalaman global mengenai materi baru tersebut sehingga siswa terpanggil secara emosional dan intelektual. Dengan kata lain, kebermaknaan dari materi yang akan diajarkan oleh guru membuat siswa tertarik untuk mempelajarinya lebih lanjut.

Tahap kedua adalah membentuk koneksi awal untuk materi pelajaran yang baru. Guru dapat mendorong siswanya untuk bereksplorasi dan mau mencari tahu sendiri mengenai materi baru tersebut. Selanjutnya, siswa diberi kebebasan dalam bereksplorasi. Siswa juga memiliki kesempatan untuk bertanya secara terbuka, berpendapat, bereaksi terhadap pengalaman global yang diberikan oleh guru.

Tahap ketiga adalah eksplorasi yang mendalam melalui penelitian dan proyek. Guru dapat memberi siswa suatu proyek yang menunjukkan aspek unik dari materi yang sedang dipelajari oleh siswa tersebut. Tahap ini memberi siswa kesempatan untuk menggunakan banyak sumber di luar buku teks dan literatur. Sumber tersebut dapat diperoleh dari internet, penggunaan software tertentu, arahan guru, atau informasiinformasi dari orang yang berpengalaman.

Tahap perantara adalah mengaktifkan kegiatan ketiga tahap di atas, khususnya tahap ketiga. Guru dapat memberikan pertanyaan-pertanyaan open-ended, memberikan pendapat, memberikan arahan langsung jika diperlukan agar siswa dapat mengkonsolidasikan pengetahuan yang penting dan keterampilannya.

Tahap keempat adalah konsolidasi, yaitu tahap dimana guru melihat hasil pekerjaan siswa, dapat berupa presentasi, pameran, atau proyek akhir yang telah siswa buat. Pada tahap ini, guru juga akan menentukan rencana apa yang akan dilakukan selanjutnya dan bagaimana cara memancing minat siswa serta bagaimana merancang pengalaman global untuk materi yang akan dibahas berikutnya.

Lebih lanjut, format belajar yang mendukung pembelajaran dengan pendekatan BBL adalah belajar melingkar atau learning circle (LC). Langkah-langkah dalam LC menurut Caine et al (2005, p.239) adalah diskusi berurutan, belajar reflektif, aplikasi praktis, dan penyusunan ulang.

Langkah pertama dalam LC adalah diskusi berurutan. Siswa duduk secara melingkar dalam satu kelompok kecil (diusahakan agar semua anggota kelompok dapat melihat satu sama lain) untuk mendiskusikan suatu topik tertentu. Dipilih salah satu siswa sebagai pemim- 
pin. Selanjutnya, siswa dapat mengungkapkan apa yang mereka ketahui mengenai topik yang dibahas. Siswa mengungkapkan pendapat secara urut. Ketika salah satu siswa berpendapat, siswa lain dilarang untuk berbicara dan cukup mendengarkan. Cara ini bertujuan untuk menggali sebanyak mungkin pengetahuan masing-masing siswa sebagai bahan diskusi. Setelah selesai, pemimpin kelompok memberi kesempatan untuk berdiskusi secara bersama-sama sehingga diperoleh satu kesimpulan kelompok.

Langkah dalam LC yang selanjutnya adalah belajar reflektif. Cara terbaik untuk menciptakan perasaan bermakna terkait materi baru bagi siswa adalah dengan menganalisisnya dan melakukan refleksi dari pengalaman siswa tersebut. Penggunaan tugas proyek sangat mendukung siswa untuk belajar reflektif. Langkah ketiga adalah aplikasi praktis. Belajar dengan praktik langsung oleh siswa akan meningkatkan kemampuan siswa terkait proyek yang diselesaikannya, baik dilakukan secara individu maupun kelompok. Melengkapi ketiga langkah tersebut, langkah keempat dalam LC adalah penyusunan ulang. Pada akhir pembelajaran, siswa pada masing-masing kelompok dapat menyusun ulang apa saja yang telah mereka pelajari dan peroleh terkait topik yang dibahas. Siswa juga dapat melakukan refleksi secara keseluruhan terkait topik tersebut.

Berdasarkan prinsip-prinsip dari BBL, Duman (2006, p.23) menemukan bahwa pembelajaran dengan pendekatan BBL tidak hanya meningkatkan prestasi akademik tetapi juga memberikan motivasi yang baik bagi para siswa dan guru dengan adanya suasana kelas yang kondusif, usaha bersama, dan minat. Oleh karena itu, pembelajaran dengan pendekatan BBL diharapkan dapat memfasilitasi siswa untuk berpikir lebih positif dalam mengembangkan ide-idenya. Ide-ide tersebut dapat disampaikan secara lisan maupun tulisan kepada siswa lain, guru, atau orang lain. Dengan kata lain, pendekatan BBL berpotensi dapat mengembangkan kemampuan komunikasi dan self-efficacy siswa. Oleh karena itu, penelitian ini dilakukan dengan tujuan untuk mengetahui bagaimana pengaruh pendekatan BBL terhadap kemampuan komunikasi mate-matis (KKMAT) dan self-efficacy (SE) siswa.

\section{METODE PENELITIAN}

Pendekatan yang digunakan dalam penelitian ini adalah pendekatan kuantitatif yaitu eksperimen semu. Penelitian eksperimen semu dipilih karena penempatan subjek-subjek dalam suatu kelompok yang akan diteliti tidak dilakukan secara acak (Salkind, 2008, p.375).

Penelitian ini dilakukan di SMAN 1 Jetis, Kabupaten Bantul, D. I. Yogyakarta. Penelitian dilaksanakan pada semester genap pada bulan Maret sampai dengan bulan Juni, tahun pelajaran 2012/ 2013.

Populasi penelitian ini adalah seluruh siswa kelas XI IPA SMA N 1 Jetis D. I. Yogyakarta pada semester kedua tahun ajaran 2012/2013 yang terdiri atas tiga kelas. Dua kelas dipilih sebagai sampel penelitian, yaitu kelas eksperimen dan kelas kontrol. Kedua kelas sampel tidak dibentuk dengan cara menempatkan secara acak subjek-subjek penelitian ke dalam kelas sampel tersebut, melainkan menggunakan kelaskelas yang ada. Kelas XI IPA 1 diberi perlakuan menggunakan pendekatan BBL, dan kelas XI IPA 2 diberi perlakuan secara konvensional. Masing-masing kelas terdiri atas 25 siswa.

Desain dalam penelitian ini adalah grup kontrol tidak secara acak (nonrandomized control group design) dengan pemberian tes awal dan tes akhir yang mengadopsi desain grup kontrol tes awal-tes akhir (pretest-posttest group control design) pada penelitian eksperimen murni. Pada awal dan akhir pembelajaran, siswa kedua kelas diberi tes awal dan tes akhir yaitu tes kemampuan komunikasi matematika. Selain itu, siswa kedua kelas juga diberi skala self-efficacy.

Instrumen tes, berupa soal, digunakan untuk mengukur KKMAT yang meliputi aspek ketepatan, kesesuaian, dan kejelasan terkait pokok bahasan limit dan turunan fungsi. Intrumen tersebut mencakup aspek-aspek: (1) ketepatan, yaitu melakukan prosedur matematis secara tepat serta memberikan keterangan dan skala yang sesuai pada diagram, grafik, model, dan tabel, (2) kesesuaian, yaitu memberikan alasan yang masuk akal (logis) sesuai dengan solusi, konsep, atau penjelasan yang diberikan, (3) kejelasan, yaitu memberikan penjelasan efektif secara terperinci bagaimana masalah diselesaikan.

Instrumen nontes, berupa skala psikologi model Likert, digunakan untuk mengukur selfefficacy siswa dengan 4 kategori respon, yaitu sangat sesuai (SS), sesuai (S), tidak sesuai (TS), dan sangat tidak sesuai (STS). Skala self-efficacy terdiri atas 12 butir pernyataan positif dan 10 butir pernyataan negatif. Skala tersebut mencakup aspek-aspek: (1) tingkatan, yaitu keyakinan siswa dalam menghadapi soal atau tugas matematika yang diberikan tergantung dari 
derajat kesulitannya, (2) kekuatan, yaitu keyakinan siswa terhadap kompetensi yang dimilikinya (termasuk di dalamnya adalah penilaian diri) dan usaha (kegigihan, kemantapan, ketekunan) yang mampu dilakukannya dalam mempelajari matematika, (3) keumuman, yaitu keyakinan siswa mampu menyelesaikan berbagai jenis soal atau tugas matematika yang diberikan.

Data-data yang dideskripsikan pada penelitian ini adalah skor KKMAT maupun skor selfefficacy siswa yang terdiri atas skor minimum, skor maksimum, rerata, simpangan baku, varians, dan persentase. Skor SE siswa merupakan skor akhir yang didasarkan pada hasil penskalaan respon menggunakan metode rating yang dijumlahkan (method of summated rating). Skor ideal untuk KKMAT dan SE dalam penelitian ini berturut-turut adalah 60 dan 86 .

Untuk kriteria ketuntasan belajar digunakan Kriteria Ketuntasan Minimal (KKM) untuk mata pelajaran matematika kelas XI IPA di SMAN 1 Jetis yaitu siswa dinyatakan tuntas jika mendapat skor minimal 75 atau $75 \%$ dari skor maksimal 100. Oleh karena itu, dengan sedikit modifikasi untuk KKMAT digunakan kriteria ketuntasan minimal $75 \%$ dari skor ideal, yaitu 45. Kriteria minimal untuk self-efficacy siswa adalah 60\% dari skor ideal, yaitu 51,6. Untuk lebih jelasnya, berikut disajikan peng-kategorian untuk skor KKMAT dan SE siswa.

Tabel 1. Kategori KKMAT dan SE Siswa

\begin{tabular}{cccc}
\hline \multicolumn{2}{c}{ KKMAT } & \multicolumn{2}{c}{ Self-efficacy } \\
\hline Skor $(\mathbf{X})$ & Kategori & Skor $(\mathbf{X})$ & Kategori \\
\hline $\mathrm{X}<33$ & Rendah & $\mathrm{X}<17,2$ & Sangat \\
$33 \leq \mathrm{X}<45$ & Sedang & $17,2 \leq \mathrm{X}<34,4$ & Rendah \\
$\mathrm{X} \geq 45$ & Tinggi & $34,4 \leq \mathrm{X}<51,6$ & Sedang \\
& & $51,6 \leq \mathrm{X}<68,8$ & Tinggi \\
& & $\mathrm{X} \geq 68,8$ & Sangat \\
& & Tinggi \\
\hline
\end{tabular}

Selanjutnya, data penelitian dianalisis menggunakan uji t untuk mengetahui keefektifan pembelajaran dengan pendekatan BBL ditinjau dari KKMAT maupun SE siswa.. Selanjutnya, untuk mengetahui pengaruh pembelajaran $\mathrm{BBL}$, pembelajaran dengan pendekatan $\mathrm{BBL}$ dibandingkan pembelajaran secara konvensional digunakan uji lanjut berupa uji individual setelah dilakukan uji MANOVA. Keputusan diambil pada taraf sigifikansi 5\%.

Sebelum dilakukan uji t terlebih dahulu harus dipenuhi asumsi kenormalan univariat menggunakan uji Kolmogorov Smirnov. Sedangkan untuk uji MANOVA, terlebih dahulu harus dipenuhi dua asumsi yaitu kenormalan multivariat dan keragaman antar kelompok sama. Pemeriksaan kenormalan multivariat dilakukan dengan menentukan nilai jarak kuadrat (mahalanobis) $d_{i}^{2}$ untuk setiap titik pengamatan pada masing-masing pembelajaran. Data dikatakan berasal dari populasi berdistribusi normal multivariat, jika sekitar $50 \%$ nilai $d_{i}^{2}<\chi_{0,5 p}^{2}$ dengan $d_{i}^{2}$ adalah jarak mahalanobis setiap pengamatan dengan vektor rata-ratanya, $i=1,2, \ldots, n$. Karena terdiri atas 2 level, maka $p=2$, sehingga diperoleh kriteria nilai $\chi_{(0.5,2)}^{2}=1,386$. Uji asumsi homogenitas mempunyai tujuan untuk mengetahui apakah kedua kelompok eksperimen mempunyai matriks varians-kovarians yang homogen atau menggunakan uji Levene-uji Box $M$.

Dalam penelitian ini, pembelajaran dengan pendekatan BBL dikatakan berpengaruh terhadap KKMAT dan self-efficacy siswa jika: (1) terdapat perbedaan pembelajaran BrainBased Learning dan pembelajaran secara konvensional ditinjau dari KKMAT maupun selfefficacy siswa. (2) Pembelajaran Brain-Based Learning lebih unggul dibandingkan pembelajaran secara konvensional ditinjau dari KKMAT maupun self-efficacy siswa.

\section{HASIL DAN PEMBAHASAN}

Data yang diperoleh dalam penelitian ini terdiri atas skor kemampuan komunikasi matematis dan skor self-efficacy siswa. Berikut berturut-turut disajikan deskripsi data pada Tabel 2 dan diagram dari skor rata-rata kemampuan komunikasi matematis siswa pada Gambar 1.

Tabel 2. Deskripsi Data KKMAT

\begin{tabular}{ccccc}
\hline \multirow{2}{*}{ Ukuran Statistik } & \multicolumn{2}{c}{ BBL } & \multicolumn{2}{c}{ Konvensional } \\
\cline { 2 - 5 } & \multicolumn{2}{c}{$\mathrm{n}=25$} & \multicolumn{2}{c}{$\mathrm{n}=25$} \\
\cline { 2 - 5 } $\boldsymbol{P r e}$ & Post & Pre & Post \\
\hline Maksimal & 24 & 58 & 21 & 49 \\
Minimal & 7 & 40 & 7 & 30 \\
Rata-rata & 14,96 & 47,68 & 13,16 & 37,92 \\
Simpangan Baku & 4,18 & 4,70 & 3,75 & 5,73 \\
\hline
\end{tabular}

Keterangan: Skor ideal adalah $60 ; \mathrm{n}=$ banyak siswa 


\section{EF}

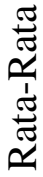

\begin{tabular}{|l|l|}
\hline 14,96 & 13,16 \\
\hline 47,68 & 37,92 \\
\hline
\end{tabular}

Gambar 1. Diagram Rata-rata Skor KKMAT Siswa

Berdasarkan Tabel 2 dan Gambar 1, ratarata skor KKMAT siswa pada saat tes awal dan tes akhir masing-masing untuk pembelajaran dengan pendekatan BBL dan pembelajaran secara konvensional mengalami peningkatan. Akan tetapi, rata-rata skor kemampuan komunikasi matematis siswa yang mengikuti pembelajaran dengan pendekatan BBL lebih baik dibandingkan dengan siswa yang mengikuti pembelajaran secara konvensional. Selanjutnya, untuk mengetahui banyak siswa yang telah memenuhi KKM dilihat dari skor tes akhir KKMAT, pada Tabel 3 berikut disajikan tabel distribusi frekuensinya.

Tabel 3. Distribusi Frekuensi Tes Akhir KKMAT Siswa

\begin{tabular}{cccccc}
\hline \multirow{2}{*}{ Skor $(\mathbf{X})$} & \multicolumn{2}{c}{ BBL } & \multicolumn{2}{c}{ KON } & \multirow{2}{*}{ Kategori } \\
\cline { 2 - 5 } & $\mathbf{f}$ & $\boldsymbol{\%}$ & $\mathbf{f}$ & $\boldsymbol{\%}$ & \\
\hline $\mathrm{X}<33$ & 0 & 0 & 5 & 20 & Rendah \\
$33 \leq \mathrm{X}<45$ & 6 & 24 & 16 & 64 & Sedang \\
$\mathrm{X} \geq 45$ & 19 & 76 & 4 & 16 & Tinggi \\
\hline Keterangan: f & Frekunn
\end{tabular}

Keterangan: $\mathrm{f}=$ Frekuensi

Berdasarkan Tabel 3, pada kelas BBL terlihat bahwa banyak siswa yang mendapatkan nilai lebih dari atau sama dengan 45 adalah 19 siswa. Artinya, siswa yang sudah mencapai standar ketuntasan minimal KKMAT adalah $76 \%$. Sedangkan pada kelas konvensional hanya 4 siswa atau 16\% saja. Rata-rata skor tiap aspek KKMAT siswa disajikan pada Tabel 4.

Tabel 4. Rata-rata Skor Tiap Aspek KKMAT

\begin{tabular}{lccccc}
\hline \multirow{2}{*}{ Aspek } & Skor & \multicolumn{2}{c}{ BBL } & \multicolumn{2}{c}{ KON } \\
\cline { 3 - 6 } & Ideal & Pre & Post & Pre & Post \\
\hline Ketepatan & 3,20 & 0,68 & 3,11 & 0,72 & 2,56 \\
Kesesuaian & 3,00 & 0,83 & 1,74 & 0,50 & 1,42 \\
Kejelasan & 3,20 & 0,94 & 2,20 & 0,83 & 1,56 \\
\hline
\end{tabular}

Berdasarkan Tabel 4, diketahui bahwa pada tes akhir untuk semua aspek KKMAT, siswa yang mengikuti pembelajaran dengan pendekatan BBL memiliki rata-rata skor lebih baik daripada siswa yang mengikuti pembelajaran secara konvensional.

Tabel 5. Deskripsi Data SE

\begin{tabular}{ccccc}
\hline \multirow{2}{*}{ Ukuran } & \multicolumn{2}{c}{ BBL } & \multicolumn{2}{c}{ Konvensional } \\
\cline { 2 - 5 } Statistik & \multicolumn{2}{c}{$\mathbf{n = 2 5}$} & \multicolumn{2}{c}{$\mathbf{n = 2 5}$} \\
\cline { 2 - 5 } & Pre & Post & Pre & Post \\
\hline Maksimal & 57 & 74 & 51 & 66 \\
Minimal & 21 & 44 & 24 & 34 \\
Rata-rata & 38,44 & 57,00 & 37,64 & 47,16 \\
Simpangan Baku & 9,99 & 8,66 & 8,18 & 8,97 \\
\hline
\end{tabular}

Keterangan: Skor ideal adalah $86 ; \mathrm{n}=$ banyak siswa

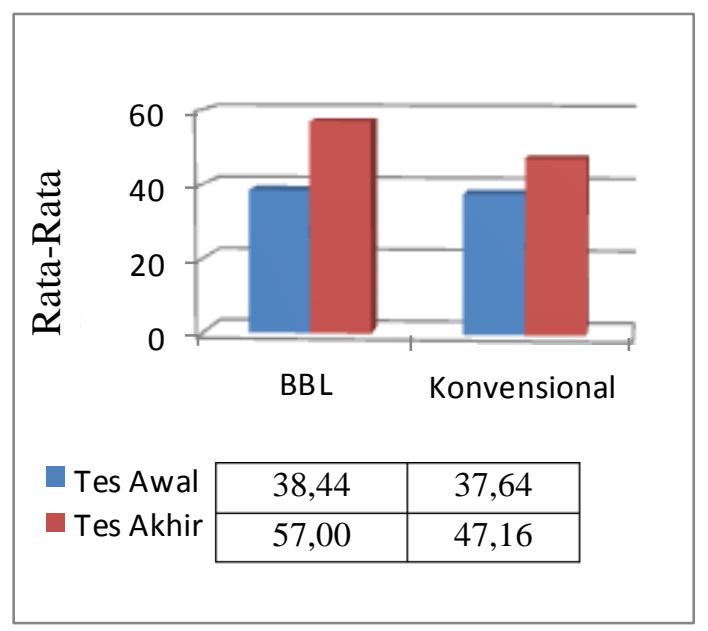

Gambar 2. Diagram Rata-rata Skor SE Siswa

Berdasarkan Tabel 5 dan Gambar 2, ratarata skor SE siswa pada saat tes awal dan tes akhir masing-masing untuk pembelajaran dengan pendekatan BBL dan pembelajaran secara konvensional juga mengalami peningkatan. Akan tetapi, rata-rata skor self-efficacy siswa yang mengikuti pembelajaran dengan pendekatan BBL lebih baik dibandingkan dengan siswa yang mengikuti pembelajaran secara konvensional.

Tabel 6. Distribusi Frekuensi Tes Akhir SE Siswa

\begin{tabular}{cccccc}
\hline \multirow{2}{*}{ Skor $(\mathbf{X})$} & \multicolumn{2}{c}{ BBL } & \multicolumn{2}{c}{ KON } & \multirow{2}{*}{ Kategori } \\
\cline { 2 - 5 } & $\mathbf{f}$ & $\%$ & $\mathbf{f}$ & $\%$ & \\
\hline $\mathrm{X}<17,2$ & 0 & 0 & 0 & 0 & Sangat \\
$17,2 \leq \mathrm{X}<34,4$ & 0 & 0 & 2 & 8 & Rendah \\
$34,4 \leq \mathrm{X}<51,6$ & 8 & 32 & 16 & 64 & Sedah \\
$51,6 \leq \mathrm{X}<68,8$ & 13 & 52 & 7 & 28 & Tinggi \\
$\mathrm{X} \geq 68,8$ & 4 & 16 & 0 & 0 & Sangat \\
& & & & &
\end{tabular}

Keterangan: $\mathrm{f}=$ Frekuensi

Berdasarkan Tabel 6, diketahui bahwa pada kelas BBL, banyak siswa yang mendapatkan 
skor lebih dari atau sama dengan 51,6 adalah 17 siswa. Artinya, banyak siswa yang telah memenuhi kriteria minimal adalah sebesar $68 \%$. Sedangkan pada kelas konvensional hanya 7 siswa atau $28 \%$ saja.

Tabel 7 menunjukkan bahwa pada tes akhir untuk semua aspek SE, siswa yang mengikuti pembelajaran dengan pendekatan BBL memiliki rata-rata skor lebih baik daripada siswa yang mengikuti pembelajaran secara konvensional.

Tabel 7. Rata-rata Skor Tiap Aspek SE Siswa

\begin{tabular}{lccccc}
\hline \multirow{2}{*}{ Aspek } & Skor & \multicolumn{2}{c}{ BBL } & \multicolumn{2}{c}{ KON } \\
\cline { 3 - 6 } & Ideal & Pre & Post & Pre & Post \\
\hline Tingkatan & 16,00 & 8,2 & 11,40 & 7,80 & 10,04 \\
Kekuatan & 55,00 & 22,88 & 33,60 & 21,96 & 27,24 \\
Keumuman & 15,00 & 7,32 & 12,00 & 7,88 & 9,88 \\
\hline
\end{tabular}

Data penelitian ini dianalisis untuk mengetahui keefektifan pembelajaran dengan pendekatan BBL dan pembelajaran secara konvensional berdasarkan skor tes akhir ditinjau dari kemampuan komunikasi matematis maupun self-efficacy siswa. Analisis keefektifan menggunakan uji t. Sebelum dilakukan uji t terlebih dahulu harus dipenuhi asumsi normalitas univariat untuk masing-masing data menggunakan uji Kolmogorov Smirnov.

Tabel 8. Hasil Uji Kolmogorov Smirnov

\begin{tabular}{cccc}
\hline \multirow{2}{*}{ Kelas } & \multirow{2}{*}{ Variabel } & \multicolumn{2}{c}{ Signifikansi } \\
\cline { 3 - 4 } & & Pre & Post \\
\hline \multirow{2}{*}{ BBL } & KKMAT & 0,918 & 0,881 \\
& SE & 0,998 & 0,833 \\
KON & KKMAT & 0,959 & 0,838 \\
& SE & 0,861 & 0,968 \\
\hline
\end{tabular}

Untuk data tes awal dan tes akhir, berdasarkan Tabel 8 diketahui bahwa nilai probabilitas uji Kolmogorov Smirnov secara keseluruhan adalah lebih dari taraf signifikansi 0,05 sehingga $\mathrm{H}_{0}$ diterima. Artinya, semua data baik tes awal maupun tes akhir berasal dari populasi yang berdistribusi normal.

Untuk mengetahui keunggulan pembelajaran dengan pendekatan BBL dibandingkan pembelajaran secara konvensional digunakan uji lanjut berupa uji individual setelah dilakukan uji MANOVA. Sebelum uji MANOVA, terlebih dahulu harus dipenuhi dua asumsi yaitu kenormalan multivariat dan keragaman antar kelompok sama. Hasil uji normalitas KKMAT dan self-efficacy sebelum dan sesudah pembelajaran siswa baik pada kelas BBL maupun kelas konvensional disajikan pada Tabel 9.
Tabel 9. Hasil Uji Normalitas

\begin{tabular}{ccc}
\hline \multirow{2}{*}{ Kelas } & \multicolumn{2}{c}{$d_{i}^{2}$} \\
\cline { 2 - 3 } & Pre & Post \\
\hline BBL & $40 \%$ & $52 \%$ \\
Konvensional & $40 \%$ & $40 \%$ \\
\hline
\end{tabular}

Berdasarkan Tabel 9, hanya pada pretes kelas BBL diperoleh nilai $d_{i}^{2}$ yang kurang dari $\chi_{(2,0,5)}^{2}=1,386294$ sekitar $50 \%$. Oleh karena itu, dapat dikatakan bahwa data pretes kelas BBL berasal dari populasi berdistribusi normal multivariat, sedangkan untuk data yang lain nilai $d_{i}^{2}$ yang kurang dari $\chi_{(2,0,5)}^{2}=1,386294$ jauh dari $50 \%$, sehingga populasi tidak normal multivariate. Akan tetapi karena ukuran sampel cukup besar $(\mathrm{n}=25)$, uji multivariat dapat dilanjutkan, karena uji $\mathrm{F}$ pada MANOVA robust terhadap asumsi ketidaknormalan multivariat.

Untuk uji homogenitas, berdasarkan Tabel 10 diketahui bahwa nilai probabilitas uji Levane untuk data tes awal KKMAT dan SE siswa berturut-turut adalah 0,589 dan 0,363 , dan untuk tes akhir KKMAT dan SE berturut-turut 0,242 dan 0,871. Sedangkan dari Tabel 11 diketahui nilai probabilitas uji Box $M$ tes awal tersebut adalah 0,668 dan tes akhir 0,071. Semua nilai probabilitas tersebut lebih dari taraf signifikansi 0,05 , sehingga pada tes awal, varians masing-masing variabel terikat kedua kelas sama, dan matriks varians dan kovarians kedua kelas sama.

Tabel 10. Hasil Uji Levene

\begin{tabular}{ccc}
\hline & & Sig. \\
\hline Pre & KKMAT & 0,589 \\
& SE & 0,363 \\
Post & KKMAT & 0,242 \\
& SE & 0,871 \\
\hline
\end{tabular}

Tabel 11. Hasil Uji Box $M$

\begin{tabular}{ccc}
\hline & Pre & Post \\
\hline Box's $M$ & 1,638 & 7,358 \\
F & 0,521 & 2,342 \\
Sig. & 0,668 & 0,071 \\
\hline
\end{tabular}

Hasil analisis telah menunjukkan bahwa semua data, baik tes awal maupun tes akhir, memenuhi asumsi berdistribusi normal dan kelompok-kelompok data terkait uji MANOVA memiliki matriks varians-kovarians yang sama. Karena kedua asumsi dipenuhi, maka uji t dan uji MANOVA dapat dilakukan.

Berikut hipotesis uji $t$ untuk pembelajaran dengan pendekatan BBL ditinjau dari KKMAT. 
H0: Pembelajaran dengan pendekatan BBL tidak efektif ditinjau dari KKMAT siswa.

H1: Pembelajaran dengan pendekatan BBL efektif ditinjau dari KKMAT siswa.

Secara statistik, hipotesis tersebut dapat dituliskan sebagai berikut.

$\mathrm{H}_{0}: \mu_{0} \leq 45$

$\mathrm{H}_{1}: \mu_{0}>45$

Selanjutnya, hipotesis uji $t$ untuk pembelajaran dengan pendekatan BBL ditinjau dari SE adalah sebagai berikut.

H0: Pembelajaran dengan pendekatan BBL tidak efektif ditinjau dari SE siswa.

H1: Pembelajaran dengan pendekatan BBL efektif ditinjau dari SE siswa.

Secara statistik, hipotesis tersebut dapat dituliskan sebagai berikut.

$\mathrm{H}_{0}: \mu_{0} \leq 51,6$

$\mathrm{H}_{1}: \mu_{0}>51,6$

Hasil analisis dengan bantuan SPSS 16, ditinjau dari KKMAT siswa yang mengikuti pembelajaran dengan pendekatan BBL memiliki $\mathrm{t}_{\text {hit }}$ sebesar 2,848. Jika dikaitkan dengan kriteria pengujian diperoleh bahwa $\mathrm{t}_{\text {hit }}>\mathrm{t}_{\mathrm{tab}(0,05 ; 24)}=$ 2,064, maka $\mathrm{H}_{0}$ ditolak. Jadi, pembelajaran dengan pendekatan BBL efektif ditinjau dari KKMAT siswa.

Selanjutnya, ditinjau dari SE siswa yang mengikuti pembelajaran dengan pendekatan BBL memiliki $t_{\text {hit }}$ sebesar 3,116. Jika dikaitkan dengan kriteria pengujian diperoleh bahwa $t_{\text {hit }}>$ $\mathrm{t}_{\mathrm{tab}(0,05 ; 24)}=2,064$, maka $\mathrm{H}_{0}$ ditolak. Jadi, pembelajaran dengan pendekatan BBL efektif ditinjau dari SE siswa.

Setelah dilakukan uji t, untuk mengetahui perbedaan kemampuan komunikasi matematis dan self-efficacy siswa pada kedua pembelajaran digunakan uji MANOVA. Hipotesis uji MANOVA adalah sebagai berikut.

$\mathrm{H}_{0}$ : Tidak terdapat perbedaan antara pendekatan BBL dengan konvensional ditinjau dari KKMAT maupun SE.

$\mathrm{H}_{1}$ : Terdapat perbedaan antara pendekatan BBL dengan konvensional ditinjau dari KKMAT maupun SE.

Secara statistik, hipotesis tersebut dapat di simbolkan sebagai berikut:
$\mathrm{H}_{0}:\left(\begin{array}{l}\mu_{11} \\ \mu_{21}\end{array}\right)=\left(\begin{array}{l}\mu_{12} \\ \mu_{22}\end{array}\right)$
$\mathrm{H}_{1}:\left(\begin{array}{l}\mu_{11} \\ \mu_{21}\end{array}\right) \neq\left(\begin{array}{l}\mu_{12} \\ \mu_{22}\end{array}\right)$

dimana $\mu_{11}$ menyatakan rerata (mean) dari skor KKMAT siswa yang mengikuti pembelajaran dengan pendekatan BBL, sedangkan $\mu_{12}$ menyatakan rerata (mean) dari skor KKMAT siswa yang mengikuti pembelajaran secara konvensional. Selanjutnya, $\mu_{21}$ menyatakan rerata (mean) dari skor SE siswa yang mengikuti pembelajaran dengan pendekatan BBL dan $\mu_{22}$ menyatakan rerata (mean) dari skor SE siswa yang mengikuti pembelajaran secara konvensional.

Hipotesis-hipotesis tersebut diuji pada taraf signifikansi 0,05 . Jika hasil uji MANOVA menunjukkan terdapat perbedaan antara kedua pendekatan pembelajaran, dengan membandingkan rata-rata skor KKMAT dan SE, maka dapat dilanjutkan dengan pengujian individual untuk masing-masing KKMAT dan SE di kedua pendekatan pembelajaran tersebut untuk mengetahui pembelajaran mana yang lebih unggul.

\section{KKMAT.}

Berikut hipotesis individual ditinjau dari

H0: Pembelajaran dengan pendekatan BBL tidak lebih unggul dibandingkan dengan pembelajaran secara konvensional ditinjau dari KKMAT siswa.

H1: Pembelajaran dengan pendekatan BBL lebih unggul dibandingkan dengan pembelajaran secara konvensional ditinjau dari KKMAT siswa.

Secara statistik, hipotesis tersebut dapat dituliskan sebagai berikut.

$\mathrm{H}_{0}: \mu_{11} \leq \mu_{12}$

$\mathrm{H}_{1}: \mu_{11}>\mu_{12}$

Selanjutnya, hipotesis uji individual ditinjau dari SE adalah sebagai berikut.

H0: Pembelajaran dengan pendekatan BBL tidak lebih unggul dibandingkan dengan pembelajaran secara konvensional ditinjau dari SE siswa.

H1: Pembelajaran dengan pendekatan BBL lebih unggul dibandingkan dengan pembelajaran secara konvensional ditinjau dari SE siswa.

Secara statistik, hipotesis tersebut dapat dituliskan sebagai berikut. 
$\mathrm{H}_{0}: \mu_{21} \leq \mu_{22}$

$\mathrm{H}_{1}: \mu_{21}>\mu_{22}$

Untuk tes awal, dari Tabel 12 diketahui bahwa nilai probabilitas uji Wilk Lambda adalah 0,246 dengan harga $F=1,444$. Nilai probabilitas tersebut lebih dari taraf signifikansi 0,05 sehingga $\mathrm{H}_{0}$ diterima. Artinya, tidak terdapat perbedaan KKMAT dan SE di kedua kelas. Dengan kata lain, kondisi awal pada kedua kelas ditinjau dari KKMAT dan SE adalah sama.

Tabel 12. Hasil Uji MANOVA

\begin{tabular}{ccccc}
\hline \multirow{2}{*}{ Analisis } & \multicolumn{2}{c}{ Pre } & \multicolumn{2}{c}{ Post } \\
\cline { 2 - 5 } & F & Sig. & F & Sig. \\
\hline Wilk's Lambda & 1,44 & 0,25 & 21,42 & 0,00 \\
\hline
\end{tabular}

Untuk tes akhir, dari Tabel 12 diketahui bahwa nilai probabilitas uji Wilk Lambda adalah 0,000 dengan harga $F=21,423$. Nilai probabilitas tersebut kurang dari taraf signifikansi 0,05 sehingga $\mathrm{H}_{0}$ ditolak. Artinya, terdapat perbedaan antara pembelajaran dengan pendekatan BBL dengan konvensional ditinjau dari KKMAT dan SE. Selain itu, karena $\mathrm{H}_{0}$ ditolak maka dapat dilakukan pengujian individual untuk masing-masing KKMAT dan SE pada kedua pembelajaran.

Tabel 13. Hasil Uji Individual terhadap Tes Akhir KKMAT dan SE

\begin{tabular}{cc}
\hline Variabel & Sig. \\
\hline KKMAT & 0,000 \\
SE & 0,000 \\
\hline
\end{tabular}

Berdasarkan hasil pengujian individual pada Tabel 13 diperoleh bahwa nilai probabilitas uji untuk KKMAT adalah 0,000. Nilai tersebut kurang dari nilai signifikansi 0,05 sehingga $\mathrm{H}_{0}$ ditolak. Dengan kata lain, pembelajaran dengan pendekatan BBL lebih unggul dibandingkan pembelajaran secara konvensional ditinjau dari KKMAT siswa.

Sedangkan ditinjau dari SE, diperoleh nilai probabilitas uji sebesar 0,000 . Nilai tersebut juga kurang dari nilai signifikansi 0,05 sehingga $\mathrm{H}_{0}$ juga ditolak. Oleh karena itu, pembelajaran dengan pendekatan BBL juga lebih unggul dibandingkan pembelajaran secara konvensional ditinjau dari SE siswa.

Berdasarkan hasil pengujian hipotesis yang telah diuraikan tersebut, diperoleh bahwa pembelajaran dengan pendekatan BBL efektif ditinjau dari KKMAT dan SE siswa. Selain itu, pembelajaran secara konvensional juga efektif ditinjau dari KKMAT maupun SE siswa. Akan tetapi, pembelajaran dengan pendekatan $\mathrm{BBL}$ lebih unggul dibandingkan pembelajaran secara konvensional ditinjau dari KKMAT dan SE siswa. Oleh karena itu, dapat disimpulkan bahwa pembelajaran dengan pendekatan BBL berpengaruh terhadap kemampuan komunikasi matematis maupun self-efficacy siswa.

Pada pembelajaran dengan pendekatan BBL, sebelum memulai materi baru siswa diberikan gambaran atau contoh-contoh terkait kehidupan sehari-hari sehingga menciptakan perasaan bermakna dan membuat mereka tertarik untuk mempelajarinya lebih lanjut. Karekteristik dari pembelajaran dengan pendekatan BBL lainnya adalah pemberian suatu proyek untuk diselesaikan secara bersama-sama. Menurut Vygotsky (Arends \& Kicher, 2010, p.309), interaksi sosial dengan orang lain disekitar akan membangun ide-ide baru dan mempercepat perkembangan intelektual seseorang. Oleh karena itu, melalui proyek tersebut siswa dapat mengeksplorasi ide-ide mereka dan saling bertukar ide sebelum diperoleh kesimpulan yang benar. Dengan kata lain, pembelajaran dengan pendekatan BBL dapat mengembangkan aspek-aspek dalam kemampuan komunikasi matematis, baik secara tertulis maupun lisan.

Peran guru dalam pembelajaran dengan pendekatan BBL adalah sebagai fasilitator juga sebagai motivator. Sebagai fasilitator, guru memberikan masukan-masukan terkait bagaimana menyelesaikan masalah dengan memperhatikan grafiknya lalu mengaitkannya dengan konsep limit kiri dan limit kanan. Sebagai motivator, guru memberikan gambaran tentang bahaya penggunaan obat secara berlebihan dan secara khusus mengenai narkotika. Oleh karena itu, pendekatan BBL dapat memfasilitasi siswa dalam meningkatkan self-efficacy mereka terutama melalui pengalaman kinerja, pengalaman orang lain (teman atau guru), dan juga pendekatan verbal/sosial yang dilakukan oleh guru.

Uraian tersebut menegaskan kelebihankelebihan dari pembelajaran dengan pendekatan BBL dalam mengembangkan kemampuan komunikasi matematis dan self-efficacy siswa. Data-data penelitian ini secara umum mendukung dugaan teoritis tersebut. Hasil penelitian juga menunjukkan bahwa pembelajaran dengan pendekatan BBL berpengaruh secara signifikan terhadap KKMAT dan SE siswa.

Berdasarkan Tabel 2 untuk tes akhir, diketahui bahwa siswa yang mengikuti pembelajaran BBL memiliki rata-rata skor KKMAT 
lebih baik $(47,68)$ daripada siswa yang mengikuti pembelajaran secara konvensional $(40,16)$. Gambar 1 menunjukkan bahwa terjadi peningkatan KKMAT antara tes awal dengan tes akhir di kedua pembelajaran. Peningkatan yang terjadi pada pembelajaran dengan pendekatan BBL dan pembelajaran secara konvensional berturut-turut adalah sebesar $68,62 \%$ dan $65,30 \%$. Peningkatan tersebut relatif sama. Akan tetapi, Tabel 3 menunjukkan bahwa persentase ketuntasan siswa pada kelas BBL ditinjau dari tes akhir KKMAT adalah $76 \%$, jauh lebih besar dibandingkan kelas konvensional yang hanya $20 \%$.

Berdasarkan Tabel 5 untuk tes akhir, diketahui bahwa siswa yang mengikuti pembelajaran BBL memiliki rata-rata SE yang lebih baik $(57,00)$ daripada siswa yang mengikuti pembelajaran secara konvensional $(47,16)$. Sedangkan dari Gambar 2 diketahui bahwa terjadi peningkatan skor rata-rata SE antara tes awal dengan tes akhir di kedua pembelajaran. Peningkatan yang terjadi pada pembelajaran dengan pendekatan BBL dan pembelajaran secara konvensional berturut-turut adalah sebesar $32,56 \%$ dan 20,19\%. Sedangkan Tabel 6 menunjukkan bahwa persentase siswa kelas BBL yang sudah memenuhi kriteria minimal adalah sebesar $68 \%$, jauh lebih besar dibandingkan kelas konvensional yang hanya $28 \%$.

Untuk data tes awal yang disajikan pada Tabel 12 diketahui bahwa tidak terdapat perbedaan yang signifikan antara pembelajaran dengan pendekatakan BBL dengan pembelajaran secara konvensional bersama-sama ditinjau dari KKMAT dan SE siswa. Hasil tersebut menunjukkan bahwa kedua kelas, baik yang menggunakan pendekatan BBL maupun kelas konvensional, mempunyai KKMAT dan SE yang sama. Selain itu, tes awal juga dijadikan dasar pemilihan kedua kelas untuk diteliti sehingga pengaruh yang diperoleh pada tes akhir bukan semata-mata karena KKMAT dan SE siswa yang sejak awal berbeda. Akan tetapi, pengaruh yang terjadi pada tes akhir merupakan hasil perlakuan yang diberikan pada kedua kelas. Oleh karena itu, analisis data melalui pengujian hipotesis dilakukan hanya berdasarkan tes akhir.

Berdasarkan hasil tes akhir KKMAT dan SE diketahui melalui uji t bahwa pembelajaran dengan pendekatan BBL efektif ditinjau dari KKMAT maupun SE siswa. Selanjutnya, Tabel 12 menunjukkan hasil MANOVA bahwa terdapat perbedaan yang signifikan antara pembelajaran dengan pendekatakan BBL dengan pembelajaran secara konvensional bersama-sama ditinjau dari KKMAT dan SE siswa. Hasil pengujian individual pada Tabel 13 menunjukkan pembelajaran dengan pendekatan BBL juga lebih unggul dibandingkan pembelajaran secara konvensional ditinjau dari KKMAT dan SE siswa.

Secara rinci, diketahui bahwa rata-rata skor KKMAT dan SE siswa yang mengikuti pembelajaran dengan pendekatan BBL lebih baik dibandingkan siswa yang mengikuti pembelajaran secara konvensional. Hasil yang sama juga berlaku untuk semua aspek pada KKMAT dan SE. Temuan ini menunjukkan kuatnya pengaruh pembelajaran dengan pendekatan BBL terhadap KKMAT dan SE siswa.

\section{SIMPULAN DAN SARAN}

\section{Simpulan}

Berdasarkan pengujian hipotesis diperoleh kesimpulan bahwa pembelajaran dengan pendekatan Brain-Based Learning berpengaruh terhadap kemampuan komunikasi matematis dan self-efficacy siswa. Secara lebih rinci, diperoleh kesimpulan sebagai berikut: (1) pembelajaran dengan pendekatan Brain-Based Learning efektif ditinjau dari kemampuan komunikasi matematis maupun self-efficacy siswa SMAN 1 Jetis Bantul; (2) pembelajaran dengan pendekatan Brain-Based Learning lebih unggul dibandingkan pembelajaran secara konvensional ditinjau dari kemampuan komunikasi matematis maupun self-efficacy siswa SMAN 1 Jetis Bantul.

\section{Saran}

Pembelajaran dengan pendekatan BBL hendaknya diterapkan dalam skala yang lebih luas dan lebih mendalam sebagai salah satu alternatif untuk mengembangkan kemampuan komunikasi matematis. Pendekatan BBL ini juga dapat dijadikan alternatif untuk mengembangkan self-efficacy siswa.

Pembelajaran secara kooperatif dan kolaboratif melalui kelompok-kelompok kecil atau melalui pola belajar melingkar hendaknya dipraktikkan dalam pembelajaran matematika. Melalui pola belajar melingkar, siswa yang mempunyai kemampuan matematis relatif tinggi dapat lebih memantapkan pemahamanya dan juga keyakinan dirinya. Sedangkan siswa yang mempunyai kemampuan matematis rendah dapat memperoleh pemahaman yang lebih baik dari penjelasan teman mereka yang mungkin lebih mudah untuk dipahami. 
Peneliti lain dapat menindaklanjuti hasil penelitian ini sehingga dapat digeneralisasikan, misalnya pengambilan subjek dilakukan secara acak dan menerapkan pembelajaran dengan pendekatan BBL pada topik-topik yang lain. Kepada pemegang kebijakan pendidikan diharapkan dapat menambah fasilitas sekolah dengan menyediakan LCD di setiap kelas sehingga guru maupun siswa dapat memanfaatkan teknologi dengan baik. Selain itu, proses belajar mengajar yang dilakukan juga akan lebih optimal.

\section{DAFTAR PUSTAKA}

Arends, R. I., \& Kilcher, A. (2010). Teaching for student learning. New York, NY: Routledge.

Bandura, A. (1995). Exercise of personal and collective efficacy in changing societies. Dalam A. Bandura (Eds.). Self-efficacy in Changing Societies. New York, NY: Cambridge University Press.

Bandura, A. (1997). Self-efficacy: The exercise of control. New York, NY: W. H. Freeman and Company.

Caine, R. N., \& Caine, G. (1990). Understanding a brain-based approach to learning and teaching. Educational Leadership, 48 (2), 43-47.

Caine, R. N., et al. (2005). $12 \mathrm{brain} / \mathrm{mind}$ learning principles in action. Thousand Oaks, CA: Corwin Press.

Duman, B. (2006). The effect of brain-based instruction to improve on students' academic achievement in social studies instruction. $9^{\text {th }}$ International Conference on Engineering Education, 24, 17-25.

Hamdi, S., \& Abadi, A. (2014). Pengaruh motivasi, self-efficacy dan latar belakang pendidikan terhadap prestasi matematika mahasiswa PGSD STKIP-H dan PGMI IAIH. Jurnal Riset Pendidikan Matematika, 1(1), 77-87. doi:http://dx.doi.org/10.21831/jrpm.v1i1. 2666

Jensen, E., (1998). Teaching with the brain in mind. Alexandria, VA: ASCD.

Jensen, E. (2008). Pembelajaran berbasis kemampuan otak: Cara baru dalam pengajaran dan pelatihan (Edisi Revisi). (Terjemahan Narulita Yusron). Yogyakarta: Pustaka Pelajar.
Kilpatrick, J., Swafford, J., \& Findel, B. (2001). Adding it up: Helping children learn mathematics. Washington, DC: National Academy Press.

Kusnaeni, K., \& Retnawati, H. (2013). Problem posing dalam setting kooperatif tipe TAI Ditinjau dari kemampuan komunikasi dan pemecahan masalah. PYTHAGORAS: Jurnal Pendidikan Matematika, 8(1), 3343.

doi:http://dx.doi.org/10.21831/pg.v8i1.84 92

Liu, X., \& Koirala, H. (2009). The effect of mathematics self-efficacy on mathematics achievement of high school students. Northeastern Educational Research Association (NERA) Conference Proceedings, 30, 1-13.

Morin, L., \& Latham, G. (2000). The effect of mental practice and goal setting as a transfer of training intervention on supervisior's self-efficacy and communication skills: An Exploratory Study. Applied Psychology, 49(3), 566-578.

Muijs, D., \& Reynolds, D. (2005). Effective teaching: evidence and practice. $\left(2^{\text {nd }}\right.$ ed.). London: SAGE Publications, Ltd.

Mullis, I. V. S., et al. (2012). TIMSS 2011 international results in mathematics. Chestnut Hill, MA: TIMSS \& PIRLS International Study Center.

NCTM. (2000). Principles and standards for school mathematics. Reston, VA: National Council of Teachers of Mathematics.

Ontario Ministry of Education. (2005). The Ontario Curriculum Grades 9 and 10 Mathematics (Rev. ed.). Toronto: Queen's Printer for Ontario.

Presiden RI. (2006). Peraturan Pemerintah RI Nomor 22, Tahun 2006, tentang Standar Isi.

Presiden RI. (2007). Peraturan Pemerintah RI Nomor 41, Tahun 2007, tentang Standar Proses.

Salkind, N. J. (Ed.). (2008). Encyclopedia of educational psychology. Thousand Oaks, CA: SAGE Publications, Inc. 
Pythagoras, 11 (1), Juni 2016 - 24

Heru Sukoco, Ali Mahmudi

Sousa, D. A. (2008). How the brain learns mathematics. Thousand Oaks, CA: Corwin Press.

The Secretary's Commission on Achieving Necessary Skill. (1991). What work requires of schools: A SCANS report for
Amerika 2000. Diakses tanggal 20 Mei 2013 dari http://www.academicinnovations.com/report.html

Zimmerman, B. J. (2000). Self-efficacy: An essential motive to learn. Contemporary Educational Psychology, 25(1), 82-91. 